\title{
HUBUNGAN PERAN SEORANG PERAWAT DENGAN KUALITAS PELAYANAN KESEHATAN DALAM PROSES KEPERAWATAN
}

\author{
Sri Lailan Nazmi Saragih \\ Email : lailansaragih9@gmail.com
}

\begin{abstract}
ABSTRAK
Perawat adalah seseorang tenaga kesehatan yang telah lulus pendidikan tinggi keperawatan, baik didalam negeri maupun luar negeri yang diakuipemerintah sesuai dengan ketentuan peraturan perundang-undangan. Sedangkan keperawatan adalah suatu pekerjaan dimana tujuannya adalah merawat orang yang sedang sakit dan membutuhkan perawatan medis. Peran seorang perawat sangat berpengaruh dalam berjalan nya proses keperawatan guna untuk meningkatkan kualitas pelayanan kesehatan khususnya di institusi kesehatan. Oleh karena itu seorang perawat yang telah lulus pendidikan tinggi keperawatan harus benar-benar menjalankan profesinya dengan baik. Seorang perawat harus memiliki kemampuan berpikir kritis dalam menyelesaikan masalah dan memutuskan masalah khususnya masalah kesehatan. Peran seorang perawat dalam meningkatkan kualitas pelayanan kesehatan sangat penting. Maka untuk mencapai tujuan tersebut, perawat perlu memiliki ilmu dan pengalaman yang cukup sehingga dapat dengan mudah dalam menjalankan profesinya sebagai seorang perawat.
\end{abstract}

\section{Kata Kunci : Perawat, Peran, Kualitas Pelayanan Kesehatan}

\begin{abstract}
A nurse is a health worker who has passed higher education in nursing, both domestically and abroad, who is recognized by the government in accordance with the provisions of laws and regulations. Meanwhile, nursing is a job where the goal is to care for people who are sick and need medical care. The role of a nurse is very influential in the running of the nursing process in order to improve the quality of health services, especially in health institutions. Therefore, a nurse who has graduated from higher education in nursing must really carry out her profession well. A nurse must have the ability to think critically in solving problems and deciding problems, especially health problems. The role of a nurse in improving health services is very important. So to achieve this goal, nurses need to have sufficient knowledge and experience so that they can easily carry out their profession as a nurse.
\end{abstract}

Key Words : Nurse, Role, Quality of Health Services 


\section{LATAR BELAKANG}

Peran dapat sebut sebagai sebuah perilaku yang diharapkan suatu individu sesuai dengan status sosial yang dimilikinya. Peran yang dilakukan seorang perawat harus sesuai dengan kewenangan yang dimiliki seorang perawat. Perawat menggambarkan diri seseorang yang diatur dalam sebuah aturan yang jelas. Perawat dalam menjalankan tugasnya dimana saja ia bertugas harus menggunakan proses keperawatan. Oleh karena itu, seorang perawat harus memahami tentang konsep proses keperawatan serta mampu menerapkan proses keperawatan tersebut dimanapun perawat bertugas.

Pelayanan Keperawatan merupakan bagian dari proses keperawatan yang dapat menjadi pertimbangan keberhasilan pencapaian dalam suatu tujuan untuk meningkatkan kualitas pelayanan keperawatan disuatu institusi kesehatan maupun dimasyarakat. Kualitas pelayanan kesehatan dan proses keperawatan itu sangat berhubungan. Apabila kualitas pelayanan kesehatan berjalan dengan baik maka proses keperawatan juga berjalan dengan baik. Kualitas pelayanan kesehatan yang baik dapat meningkatkan pelayanan kesehatan disuatu institusi dan masyarakat hal ini juga dapat meningkatkan jeouasan pasien terhadap pelayanan kesehatan tersebut.

Kualitas pelayanan kesehatan juga ditentukan oleh manajemen asuhan keperawatan yang menggunakan metode proses keperawatan dalam menyelesaikan permasalahan yang ada pada pasien yang berhubungan langsung pada pengelolaan asuhan keperawatan. Salah satu upaya dalam meningkatkan pelayanan kesehatan yang bermutu adalah dengan cara menerapkan sebuah metode tim yang dapat memudahkan seorang perawat dalam bekerjasama sehingga dapat dengan mudah dalam memberikan asuhan keperawatan.

\section{METODE}

Pengkajian ini menggunakan metode kualitatif yang dilakukan dengan cara mengumpulkan sebanyak-banyaknya data untuk dianalisis, yaitu dengan menggunakan literature view yang berkenaan dengan judul pembahasan yaitu mengenai Proses Keperawatan. Adapun Literature View yang digunakan adalah Buku Teks, Buku Referensi, Jurnal Elektronik, Reasearch, dan hasil skripsi. Dengan kata kunci Peran, Kualitas Pelayanan, dan Keperawatan. Dan Literature View yang digunakan dalam 
metode ini adalah sebanyak 11 Literature View yang diterbitkan 8 tahun terakhir.

\section{HASIL}

Berdasarkan 11 Literature View yang digunakan didapatkan bahwa peran perawat, kualitas pelayanan, dan proses keperawatan itu saling berhubungan satu sama lain. Seorang perawat harus memiliki kemampuan berpikir kritis dalam menyelesaikan masalah dan memutuskan masalah khususnya masalah kesehatan. Peran seorang perawat dalam meningkatkan kualitas pelayanan kesehatan sangat penting. Maka untuk mencapai tujuan tersebut, perawat perlu memiliki ilmu dan pengalaman yang cukup sehingga dapat dengan mudah dalam menjalankan profesinya sebagai seorang perawat. Perawat sangat berperan penting dalam meningkatkan asuhan keperawatan dengan cara melakukan asuhan keperawatan dengan baik diberbagai situasi dan memikiki kemampuan berfikir kritis sehingga dapat dengan mudah memecahkan masalah yang terjadi pada pasien dan mencari solusinya. Kualitas pelayanan keperawatan yang baik juga dapat meningkatkan proses keperawatan yaitu dengan cara memberikan pelayanan kesehatan dengan baik yaitu dengan melengkapi segala fasilitas kesehatan yang dibutuhkan dalam melakukan asuhan keperawatan baik itu di masyarakat maupun di institusi kesehatan. Oleh karena itu dalam meningkatkan proses keperawatan maka pelayanan keperawatan di rumah sakit harus didasarkan pada profesionalisme dan Ilmu pengetahuan yang cukup.

\section{PEMBAHASAN}

\section{A. Konsep Proses Keperawatan}

Menurut Depkes RI dan JICA (1982), Proses keperawatan adalah suatu proses di penilaian masalah yang dinamis dalam usaha memperbaiki atau memelihara pasien sampai ke taraf optimum melalui suatu pendekatan yang sistematik untuk mengenal dan membantu pemenuhan kebutuhan khusus klien. Proses keperawatan juga dapat diartikan sebagai sebuah metoda yang digunakan dalam memberikan asuhan keperawatan kepada pasien dengan memerhatikan respon pasien terhadap gangguan kesehatan yang mereka alami.

Tujuan dari proses keperawatan adalah untuk mempraktikkan metode pemecahan masalah dalam melakukan praktik keperawatan.

Proses keperawatan mempunyai 5 komponen yang terdiri dari : 
1. Pengkajian

Pengkajian merupakan tahap awal dalam proses keperawatan yang merupakan pendekatan dalam mengumpulkan data yang kemudian akan dianalisis. Biasanya pada tahap pengkajian ini, kita akan mengkaji permasalahanpermasalahan dan data-data terkait pasien yang kemudian akan diidentifikasi . Tujuan dari pengkajian ini adalah untuk memperoleh informasi kesehatan pasien, untuk menentukan masalah keperawatan, dan juga untuk membuat keputusan dan merancang langkah-langkah yang akan dilakukan selanjutnya.

2. Diagnosa Keperawatan

Diagnosa Keperawatan adalah langkah kedua yang menggambarkan penilaian kesehatan terhadap respon pasien baik individu, keluarga, ataupun kelompok. Dimana pada tahap ini perawat berperan untuk mengatasinya.

Tujuan dari diagnose keperawatan ini adalah untuk mengidentifikasi permasalahan terakit respon pasien terhadap penyakit yang dialami, mengidentifikasi penyebab suatu penyakit tersebut, dan mengkomunikasikan permasalahan pasien dengan tim kesehatan lainnya.

Langkah-langkah dalam menentukan diagnose keperawatan ada 5 sebagai berikut.

a. Klasifikasi analisis data yaitu mengumpulkan dan mengelompokkan data-data pasien.

b. Interpretasi data

c. Menentukan masalah pasien yang pernah dialami

d. Membuat keputusan

3. Validasi Data

Pada tahap ini, perawat berperan dalam memvalidasi data-data pasien secara tepat dan akurat yang dilakukan bersama pasien dan juga anggota keluarga pasien.

4. Merumuskan Diagnosa

Keperawatan

Pada hal ini, perawat harus merumuskan diagnose keperawatan yang didasari pada identifikasi masalah dan factor-faktor penyebab yang harus sesuai dengan kebutuhan pasien.

5. Evaluasi Keperawatan

Maksud dari evaluasi keperawatan adalah perawat mengkaji respon pasien setelah dilakukan nya proses keperawatan dan mengkaji kembali asuhan keperawatan yang telah diberikan kepada pasien. 
Proses keperawatan ini sangat bermanfaat baik itu untuk pasien, tenaga keperawatan, institusi kesehatan, amupun masyarakat.

\section{B. Hubungan Karakteristik Seorang} Perawat dan Fasilitas Kesehatan dengan Kualitas Pelayanan

\section{Kesehatan}

Kualitas pelayanan kesehatan sangat dipengaruhi oleh karakteristik dalam diri seseorang khususnya karakteristik seorang perawat sebagai tenaga kesehatan. Karakteristik tersebut memiliki peranan terhadap keinginan seseorang dalam melakukan asuhan keperawatan. Perawat memberikan pengaruh besar untuk menentukan apakah institusi tempat mereka bekerja berkualitas atau tidak. Terutama dengan sikap caring yang memperhatikan pasien secara humanistic dapat meningkatkan hubungan yang harmonis antara perawat dengan pasien sehingga dapat meningkatkan kepuasan pasien.

Kepuasan pasien adalah tingkat kepuasan perasaan pasien yang timbul sebagai efek dari kinerja suatu layanan kesehatan. Dalam keperawatan, sikap caring wajib di miliki oleh semua tenaga kesehatan khususnya perawat. Karena caring ini merupakan hal terpenting dalam praktik keperawatan dan banyak yang meyakini bahwa berperilaku caring dapat menciptakan kerja sama yang baik antara perawat dengan pasien yang merupakan esensi dari keperawatan.

Peningkatan kualitas pelayanan kesehatan akan menghasilkan kepuasan serta kesetiaan atau loyalitas pasien yang dapat memenangkan persaingan dengan institusi kesehatan lainnya. Kualitas suatu fasilitas kesehatan dapat dilihat dari kelengkapan fasilitas yang diberikan. Kelengkapan fasilitas yang baik akan mempengaruhi loyalitas seorang pasien. Karena apabila fasikitas layanan kesehatan terpenuhi maka dapat membuat pasien dating ke fasilitas kesehatan yang sama.

\section{Peran Seorang Perawat dalam Menjalankan Proses Keperawatan}

Sebagai tenaga kesehatan seorang perawat memiliki peran dalam menjalankan proses keperawatan . Peran tersebut adalah :

1. Sebagai Pelaksana Layanan Keperawatan (Care Provider)

Dalam hal ini, perawat harus memberikan pelayanan berupa asuhan keperawatan secara langsung kepada pasien sesuai 
dengan kewenangan yang dimiliki

oleh seorang perawat. Dalam peran perawat sebagai care provider perawat memiliki tugas :

a. Memberi kenyamanan dan rasa aman terhadap pasien

b. Melindungi hak dan kewajiban pasien

c. Memfasilitasi pasien dengan tenaga medis lainnya

d. Berusaha keras untuk menyembuhkan pasien

2. Sebagai Pengelola (manager)

Perawat memiliki tanggung jawab dalam mengelola layanan keperawatan disemua tatanan fasilitas kesehatan maupun di tatanan pendidikan yang merupakan tanggung jawab perawat sesuai dengan konsep manajemen keperawatan.

\section{Sebagai Pendidik (Educator)}

Perawat berperan sebagai mendidik pasien baik itu individu, keluarga, maupun komunitas. Tidak hanya pasien, seorang perawat juga harus mampu memberikan pendidikan kepada tenaga kesehatan lainnya. Hal ini dilakukan sebagai upaya menciptakan perilaku kesehatan. Peran perawat sebagai pendidik ini bertujuan untuk membangun kesadaran diri dengan pengetahuan tentang kesehatan.
4. Sebagai Peneliti dan Pengembang Ilmu Keperawatan

Sebagai suatu profesi, Keperawatan harus dapat melakukan upaya untuk melakukan pengembangan diri. Zaman sekarang, banyak tantangan , persoalan, dan pertanyaan seputar keperawatan yang ditujukan kepada profesi perawat dan juga harus mampu dijawab dengan baik dan benar oleh perawat. Oleh karena itu, seprang perawat juga di tuntut untuk melakukan riset keperawatan.

\section{KESIMPULAN}

Perawat sangat berperan penting dalam meningkatkan kualitas pelayanan dalam proses keperawatan. Kualitas pelayanan keperawatan sangat dipengaruhi oleh karakteristik dan kemampuan yang dimiliki sorang perawat. Dalam hal ini perawat harus mampu memberikan asuhan keperawatan yang baik kepada klien sesuai dengan kewenangan yang dimiliki seorang perawat.Selain itu, tidak hanya perawat yang berperan namun anggota atau kelompok lainnya juga berperan dalam meemenuhi fasilitas pelayanan di institusi kesehatan mapun masyarakat. Hal ini dilakukan dalam meningkatkan 
kualitas pelayanan keperawatan dalam proses keperawatan.

\section{SARAN}

\begin{abstract}
Saran bagi seorang perawat dalam memberikan asuhan keperawatan haruslah dilakukan dengan benar dan baik karena semua nya akan menyangkut kesehatan dan keselmatan pasien. Seorang perawat harus lebih melatih diri untuk memiliki kemampuan yang memang seharusnya dimiliki oleh seorang perawat. Selain itu seorang perawat harus memiliki sikap caring sehingga pasien merasa sangat diperhatikan. Hal ini juga dilakukan untuk meningkatkan loyalitas sebuah institusi rumah sakit.
\end{abstract}

Saran bagi pihak institusi kesehatan agar lebih memotivasi perawat dalam melakukan asuhan keperawatan. Contohnya dengan memberikan hadiah sehingga perawat termotivasi lagi untuk lebih semangat dalam menjalankan profesinya, kemudian bias juga dengan memberikan pelatihan untuk para perawat agar lebih baik lagi dalam memberikan asuhan keperawatan kepada pasien atau klien.

\section{DAFTAR PUSTAKA}

Aeni, W., Winani, \& Hendri. (2019).

Perilaku Caring Perawat dalam Memberikan Asuhan Keperawatan di salah satu RS di Kabupaten Indramayu. Jurnal Keperawatan Profesional (JKP). 7(1)

Asmadi. (2005). Konsep Dasar Keperawatan. Jakarta: Penerbit Buku Kedokteran EGC.

Kasim, A. (2016). Peningkatan Kualitas Pelayanan dan Pendokumentasian Asuhan Keperawatan dengan Metode Tim. NurseLine Journal, 1(1), 63-64.

Gladis, M., \& Mulyadi. (2016). Hubungan Peran Perawat sebagai Care Giver dengan Tingkat Kepuasan Pasien Instlalasi Gawat Darurat di RSU. GMIBM Monompia Kotamobagu Kabupaten Bolaang Mongondow. E-Journal Keperawatan (e-Kp), 4(2), 2-3.

Potter, A., \& G.A, P. (2010). Fundamental Keperawatan. Jakarta: Salemba Medika.

Simamora, R.H. (2008). The correlation of ward chief's giving direction and command and the performance of on-duty nurses at Jember dr. Subandi general hospital inpatient wards. Jurnal Administrasi dan Kebijakan Kesehatan.

Yanti, R.I., \& Bambang Edi. (2019). Hubungan Karakteristik Perawat, Motivasi, dan Supervisi dengan Kualitas Dokumentasi Proses Asuhan Keperawatan. . Jurnal 
Management Keperawatan, 1(2), 109-111.

Ridwan, \& S, F. (2015). Pelayanan Fasilitas Kesehatan : Faktor Kepuasan dan Loyalitas Pasien. Jurnal Majority, 4(9), 20-22.

Rohita, T., \& Yaetty. (2017). Peningkatan Kualitas Pelayanan Keperawatan Melalui Ronde dan Pendokumentasian. Jurnal Dunia Keperawatan, 5(1), 50-51.

Simamora, R. (2019). Development of Guidelines for Applying appropriate Patient Identification to Achieve Patient Safety Goal INC2019 12th International Nursing Conference. 2019.10 455 455 (1 pages) UCI(KEPA) : I410ECN-0101-2019-512-001224337

Tiara, \& L, A. (2013). Perilaku Caring Perawat dalam Meningkatkan Kepuasan Pasien Rawat Inap. Jurnal Keperawatan, 9(2), 115116.

Mangole, J., Rompas, \& Ismayanto. (2015). Hubungan Perilajku Perawat dengan Pendokumentasian Asuhan Keperawatan di Cardivaskular dan Brain Centre RSUP Prof. Dr. R. D. kANDOU mANADO. Jurnal Keperawatan, 3(2), 2-3. 